\title{
Effect of ensiling time and exogenous protease addition to whole- plant corn silage of various hybrids, maturities, and chop lengths on nitrogen fractions and ruminal in vitro starch digestibility
}

\author{
L. F. Ferraretto, ${ }^{*}$ P. M. Crump, $†$ and R. D. Shaver ${ }^{* 1}$ \\ ${ }^{*}$ Department of Dairy Science, and \\ †Department of Computing and Biometry, University of Wisconsin, Madison 53706
}

\begin{abstract}
The objective of this study was to evaluate the effects of ensiling time and exogenous protease addition on soluble $\mathrm{CP}$ (\% of $\mathrm{CP}$ ), ammonia-N (\% of $\mathrm{N}$ ), and ruminal in vitro starch digestibility (ivSD) of wholeplant corn silage (WPCS) from 3 hybrids, 2 maturities, and 2 chop lengths. Samples from 3 nonisogenic hybrids [brown midrib containing the $b m 3$ gene mutation (BM3), dual-purpose (DP), or floury-leafy (LFY)] at 2 harvest maturities $[2 / 3$ kernel milk line (early) or $7 \mathrm{~d}$ later (late)] with 2 theoretical lengths of cut settings $(0.64$ or $1.95 \mathrm{~cm})$ on a forage harvester were collected at harvest, treated with or without exogenous protease, and ensiled in triplicate in vacuum heat-sealed plastic bags for $0,30,60,120$, and $240 \mathrm{~d}$. Thus, the experiment consisted of 120 treatments ( 3 hybrids $\times 2$ maturities $\times 2$ chop lengths $\times 2$ protease treatments $\times 5$ time points) and 360 mini-silos (3 replications per treatment). Vitreousness, measured by dissection on unfermented kernels on the day of harvest, averaged 66.8, 65.0, and $59.0 \%$ for BM3, DP, and LFY, respectively. A protease $\times$ maturity interaction was observed with protease increasing ivSD in late but not early maturity. Ensiling time $\times$ hybrid interactions were observed for ammonia-N and soluble $\mathrm{CP}$ concentrations with greater values for FLY than other hybrids only after $120 \mathrm{~d}$ of ensiling. Ensiling time $\times$ hybrid or protease $\times$ hybrid interactions were not observed for ivSD. Measurements of ivSD were greatest for FLY and lowest for BM3. Length of the ensiling period did not attenuate negative effects of kernel vitreousness or maturity on ivSD in WPCS. Results suggest that the dosage of exogenous protease addition used in the present study may reduce but not overcome the negative effects of maturity on ivSD in WPCS. No interactions between chop length and ensiling time or exogenous protease addition were observed for ivSD.
\end{abstract}

Received February 25, 2015.

Accepted August 16, 2015.

${ }^{1}$ Corresponding author: rdshaver@wisc.edu
Key words: corn silage, ensiling, protease, ruminal in vitro starch digestibility

\section{INTRODUCTION}

Starch digestibility of whole-plant corn silage (WPCS) may be affected by several factors. First, the starch endosperm is protected by the pericarp, which, if intact, is highly resistant to microbial attachment (McAllister et al., 1994); thereby, breakage of the seed coat can increase starch digestibility (Ferraretto and Shaver, 2012a,b). However, even the exposed endosperm is not fully digested due to existence of starch-protein matrices formed by the chemical bonds of zein proteins with starch granules (Kotarski et al., 1992; McAllister et al., 1993). The concentration of zein proteins in corn kernels may be affected by several factors, including nitrogen fertilization rates (Masoero et al., 2011), maturity at harvest (Ferraretto and Shaver, 2012b), fermentation (Hoffman et al., 2011), and endosperm type (Philippeau and Michalet-Doreau, 1997; Correa et al., 2002).

Recently, greater in vitro starch digestibility (ivSD) was observed for WPCS stored for a longer length of time (Der Bedrosian et al., 2012; Ferraretto et al., 2015d). The greater concentration of soluble CP (\% of $\mathrm{CP}$ ) and ammonia-N (\% CP) for WPCS with extended ensiling time in these trials imply the occurrence of proteolysis of zein proteins (Hoffman et al., 2011) or an effect of fermentation on particle size (Ferraretto et al., 2015a). Although improvement in ruminal ivSD with extended ensiling time is well established, its effects on WPCS of various hybrids, maturity, and chop length are not well understood. When WPCS was harvested at $41 \% \mathrm{DM}$, brown midrib containing the bm3 gene mutation (BM3) WPCS had similar ruminal ivSD compared with conventional WPCS as fresh forage but lower ivSD when compared after 45 to $360 \mathrm{~d}$ of ensiling (Der Bedrosian et al., 2012). In contrast, these authors observed that when WPCS was harvested at $32 \%$ DM the BM3 took $270 \mathrm{~d}$ to reach the same ivSD as conventional WPCS. To our knowledge, no studies 
have evaluated the effects of ensiling time on WPCS of various chop lengths.

Addition of exogenous protease to WPCS at ensiling has increased ivSD (Young et al., 2012). Windle et al. (2014) reported increased ivSD with both early and late maturity WPCS. However, this is the sole study found in the literature evaluating exogenous protease addition at ensiling in WPCS of varied maturities. Perhaps exogenous protease addition at ensiling to WPCS of varied hybrids may attenuate the negative effects of vitreous endosperm on starch digestibility, but to our knowledge no such studies have been published.

Although the effects of ensiling time and exogenous protease on ivSD are well established, their use as a tool to attenuate the negative effects of maturity, endosperm type, and lack of kernel processing is uncertain. Therefore, the objective of the present study was to evaluate the effects of ensiling time and exogenous protease addition on soluble CP (\% of CP), ammonia-N (\% of N), and ivSD in WPCS of various hybrids, maturities, and chop lengths. We hypothesized that ensiling WPCS for an extended time or adding an exogenous protease at ensiling would attenuate the differences in ivSD between various hybrids, maturities, and chop lengths.

\section{MATERIALS AND METHODS}

\section{Silage Production and Treatments}

A brown midrib containing the $b m 3$ gene mutation (BM3; F2F485, Mycogen Seeds, Dow AgroSciences LLC, Indianapolis, IN), a dual-purpose (DP; P960, DuPont Pioneer, Johnston, IA) and an experimental leafy-floury (LFY; GLF97, Glenn Seed Ltd., Blenheim, ON, Canada) WPCS hybrid were grown in separate field plots (6.5 ha planted at 69,000 seeds/ha for LFY, 5.4 ha planted at 86,000 seeds/ha for DP, and 5.8 ha planted at 79,000 seeds/ha for BM3) at the University of Wisconsin-Madison Agricultural Research Station (Arlington, WI) under the same tillage, fertilizer application, and weed control practices for a companion feeding trial (Ferraretto et al., 2015b). Plant population, reported as seeds planted, was targeted as recommended by respective seed company representatives. The 3 hybrids were harvested at 2 maturities, two-thirds kernel milk line (early) and $7 \mathrm{~d}$ later (late), and whole-plants were chopped at 2 theoretical lengths of cut (TLOC) settings [0.64-cm (short) or 1.95-cm (long)] on the self-propelled forage harvester (JD 6910, John Deere, Moline, IL) fitted with a conventional kernel processor (2-mm roll gap). Harvest dates were September 7, 10, and 14, 2012, for LFY, DP, and BMR, respectively, at early maturity based on kernel milk line and $7 \mathrm{~d}$ later at late maturity stage. The day of harvest, samples of the 3 hybrids, at both maturities and for both chop lengths, were treated with an experimental exogenous bacterial protease produced in Bacillus licheniformis (guaranteed protease activity against $p$-nitroaniline of 75,000 PROT units/mL; DSM Nutritional Products, Basel, Switzerland/Novozymes, Bagsvaerd, Denmark) or with an equivalent amount of distilled water that served as a control. Exogenous protease was added at a rate of $1.825 \mathrm{~mL}(1,825 \mathrm{mg})$ of protease per $\mathrm{kg}$ of corn DM to PROT treatments, which is equivalent to 136.9 PROT units per $\mathrm{kg}$ of WPCS of DM. One PROT unit is the amount of enzyme that releases $1 \mu \mathrm{mol}$ of $p$ nitroaniline from $1 \mu M$ of substrate (Suc-Ala-Ala-ProPhe-pNA) per minute at $\mathrm{pH} 9.0$ and $37^{\circ} \mathrm{C}$. This dosage matched supplier recommendations and was previously demonstrated to increase ivSD of rehydrated and highmoisture corn (Ferraretto et al., 2015c). Samples were vacuum sealed in triplicate in nylon-polyethylene standard barrier vacuum pouches (3.5-mil thickness, $25.4 \times$ $35.6 \mathrm{~cm}$; Doug Care Equipment Inc., Springville, CA) containing $600 \mathrm{~g}$ of as-fed WPCS using an external clamp vacuum machine (Bestvac; distributed by Doug Care Equipment Inc., Springville, CA) for each time point and ensiled for $0,30,60,120$, and $240 \mathrm{~d}$. Thus, the experiment consisted of 120 treatments $(3$ hybrids $\times 2$ maturities $\times 2$ chop lengths $\times 2$ protease treatments $\times 5$ ensiling time points) and 360 mini-silos (3 replications per treatment). Mini-silos were stored at room temperature (approximately $20^{\circ} \mathrm{C}$ ) in the dark until reaching the targeted ensiling time. After the ensiling time was reached, the bags were immediately frozen and stored at $-20^{\circ} \mathrm{C}$ to stop fermentation until being processed for analysis. All samples, including 240 $\mathrm{d}$, were frozen for at least $21 \mathrm{~d}$ to ensure protocol similarity among all samples. Prior to exogenous protease addition and ensiling, 2 sub-samples for each hybrid at both maturities and each chop length were collected and immediately frozen for further physical and nutrient characterization. Throughout the manuscript these sub-samples will be referred to as fresh samples, whereas samples ensiled but frozen immediately will be referred to as d 0 or whole-plant corn fresh forage.

\section{Fermentation Profile, Physical Characteristics, Nutrients, and Digestibility Analysis}

Fresh samples were analyzed undried and unground for particle size as described by Kononoff et al. (2003), whereas dried (at $60^{\circ} \mathrm{C}$ for $48 \mathrm{~h}$ in a forced-air oven) and unground samples were analyzed for corn silage processing score (Ferreira and Mertens, 2005) at the University of Wisconsin-Madison. Samples were composited by hybrid and maturity and sent to Dairyland 
Laboratories Inc. (Arcadia, WI) for analysis. Fresh samples were analyzed for DM (method 930.15, AOAC, 2012), CP (method 990.03; AOAC, 2012), boratephosphate buffer soluble CP (Krishnamoorthy et al., 1982), ammonia-N (method 973.49, AOAC, 2012), NDF (method 2002.04; AOAC, 2012), ADF (method 973.18; AOAC, 2012), lignin (method 973.18; AOAC, 2012), ether extract (method 2003.05; AOAC, 2012), ash (method 942.05; AOAC, 2012), and starch (Bach Knudsen, 1997; YSI Biochemistry Analyzer, YSI Inc., Yellow Springs, OH). The $30-\mathrm{h}$ in vitro NDF digestibility (ivNDFD) on dried 1-mm screen ground samples was performed using the Goering and Van Soest (1970) method, whereas ivSD $(7 \mathrm{~h})$ was performed on dried 4-mm ground samples using the procedures described by Richards et al. (1995). Fermentation profile was measured by HPLC as described by Muck and Dickerson (1988). Ensiled samples, including d 0, were analyzed for DM, CP, borate-phosphate buffer soluble $\mathrm{CP}$, ammonia-N, starch, ivSD, and fermentation profile as described above. Samples analyzed for ivNDFD and ivSD were dried at $60^{\circ} \mathrm{C}$ for $48 \mathrm{~h}$ in a forced-air oven, and ground to pass a 4-mm Wiley mill screen (Thomas Scientific, Swedesboro, NJ) before analysis.

\section{Kernel Sample Collection and Analysis}

On the day of harvest, 10 random ears of corn were sampled from each hybrid at both maturities for kernel characterization. Ear samples were husked and stored in a $-20^{\circ} \mathrm{C}$ freezer. All 10 ears were hand shelled while frozen and composited into one sample. Samples were sent to the University of Wisconsin Soil and Forage Analysis Laboratory (Marshfield, WI) in duplicate for the analyses described below. Samples were dried at $40^{\circ} \mathrm{C}$ for $72 \mathrm{~h}$ in a forced-air oven to determine $\mathrm{DM}$ content; low temperature was used to maintain intact kernel cell structure (Philippeau and Michalet-Doreau, 1997). Dried samples were analyzed for vitreousness by manual dissection (Correa et al., 2002), zein protein profile (Nellis et al., 2013), and in vitro gas production (as described by Hoffman et al., 2012). Briefly, in vitro gas production was measured on duplicate $0.5-\mathrm{g}$ dried and 1-mm ground corn samples using the Ankom-RFS system (Ankom Technology Corp., Macedon, NY) with wireless transponders. Samples were adjusted for the gas production in a blank sample.

\section{Statistical Analysis}

Data were analyzed as a split-split-plot design using the procedure MIXED of SAS (SAS Institute Inc., 2004). Samples from d 0 were not included in the full model to avoid confounding of ensiling time effects and interactions. The model included the fixed effects of hybrid, maturity, chop length, exogenous protease addition, ensiling time, and their 2-, 3-, and 4-way interactions with the exception of any interaction containing hybrid and maturity together. Random effects were hybrid $\times$ maturity and hybrid $\times$ maturity $\times$ chop length. Mini-silo was used as the experimental unit. Means were determined using the LSMEANS statement and were compared using the PDIFF option. Orthogonal contrasts were used to evaluate linear and quadratic

Table 1. Nutrient composition and fermentation profile of unfermented whole-plant corn ${ }^{1}$

\begin{tabular}{|c|c|c|c|c|c|c|}
\hline \multirow[b]{2}{*}{ Item } & \multicolumn{2}{|c|}{ BM3 } & \multicolumn{2}{|c|}{ DP } & \multicolumn{2}{|c|}{ LFY } \\
\hline & Early & Late & Early & Late & Early & Late \\
\hline \multicolumn{7}{|l|}{ Nutrient } \\
\hline DM (\% of as fed) & 43.2 & 48.0 & 43.8 & 49.3 & 34.3 & 38.1 \\
\hline $\mathrm{CP}(\%$ of $\mathrm{DM})$ & 7.0 & 7.5 & 6.8 & 7.2 & 7.5 & 7.8 \\
\hline Soluble CP (\% of CP) & 11.1 & 20.4 & 8.8 & 7.7 & 14.1 & 12.0 \\
\hline Ether extract (\% of DM) & 2.7 & 1.9 & 3.0 & 3.1 & 2.7 & 2.7 \\
\hline Lignin (\% of DM) & 1.4 & 1.5 & 2.2 & 2.6 & 2.6 & 3.0 \\
\hline ivNDFD $^{2}(\%$ of NDF) & 67.5 & 72.5 & 57.4 & 57.3 & 57.7 & 57.4 \\
\hline Starch $(\%$ of DM) & 40.6 & 35.3 & 42.7 & 50.1 & 30.7 & 29.4 \\
\hline ivSD $^{3}$ (\% of starch) & 52.7 & 47.4 & 57.8 & 54.0 & 61.4 & 60.2 \\
\hline Ash $(\%$ of $\mathrm{DM})$ & 5.0 & 3.0 & 3.0 & 2.7 & 3.7 & 3.9 \\
\hline \multicolumn{7}{|l|}{ Fermentation profile } \\
\hline $\mathrm{pH}$ & 5.6 & 5.7 & 5.6 & 5.7 & 5.6 & 5.5 \\
\hline
\end{tabular}

${ }^{1}$ Treatments were brown midrib containing the bm3 gene mutation (BM3), dual-purpose (DP), or leafy-floury (LFY) hybrid at 2 harvest maturities, $2 / 3$ kernel milk line (early) or $7 \mathrm{~d}$ later (late).

${ }^{2}$ Ruminal in vitro NDF digestibility at $30 \mathrm{~h}$.

${ }^{3}$ Ruminal in vitro starch digestibility at $7 \mathrm{~h}$. 
responses to ensiling time from 30 to $240 \mathrm{~d}$. Because treatments were unequally spaced, contrast coefficients were determined using the ORPOL statement within the procedure IML of SAS (SAS Institute Inc., 2004). Further analyses were performed using the same model and with d 0 samples added to the data set to evaluate fermentation effects by using an orthogonal contrast comparing d 0 versus 30 . Statistical significance and trends were declared at $P \leq 0.05$ and $P>0.05$ to $P<$ 0.10 , respectively. Because harvest measurements and unfermented kernel samples were not replicated, means are presented to characterize the material, but differences could not be tested statistically. Interactions are presented in Appendix Tables A1 and A2.

\section{RESULTS AND DISCUSSION}

\section{Fresh Sample Chemical and Physical Characteristics}

Nutrient composition and fermentation profile of fresh forage for the 3 hybrids at both harvest maturities are in Table 1. Dry matter, NDF, and starch concentrations ranged from 34.3 to $49.3 \%, 22.8$ to $39.2 \%$, and 29.4 to $50.1 \%$, respectively. Dry matter content at harvest was greater than expected, and greater than commonly recommended (Seglar and Shaver, 2014), even though a similar range was reported in a review of hybrid-type feeding trials (Ferraretto and Shaver, 2015). This variance may be partially related to harvest timing being determined by kernel milk line location (Ganoe and Roth, 1992) rather than whole-plant DM content. Accumulation of DM in the kernels was variable among hybrids at a similar harvest stage in previous trials from our laboratory (Ngonyamo-Majee et al., 2008, 2009). However, because the objective of the present study was to evaluate effects of ensiling time and exogenous protease addition on hybrids of varied endosperm types and maturities, the use of kernel milk line as an indicator of maturity was thought to be essential. Total precipitation at University of Wisconsin-Madison Arlington Agricultural Research Station during April to September of $2012(366 \mathrm{~mm})$ was less than the average of the past $20 \mathrm{yr}$ (1995 to 2014; $597 \mathrm{~mm}$; NOAA, 2015), which may have affected whole-plant DM yield and nutrient concentrations. Total amounts of DM harvested per hectare were 13.7, 13.8 and $15.2 \mathrm{Mg}$ for BM3, DP, and LFY, respectively, at early maturity. Because these were large field plots for a companion feeding trial (Ferraretto et al., 2015b), plots were not replicated and late maturity yields are unavailable; thereby statistical evaluation of the yield observations is not possible and thus no valid comparison of the potential economic effect of yield differences can be performed. Further research is warranted to evaluate the effects of these hybrids at

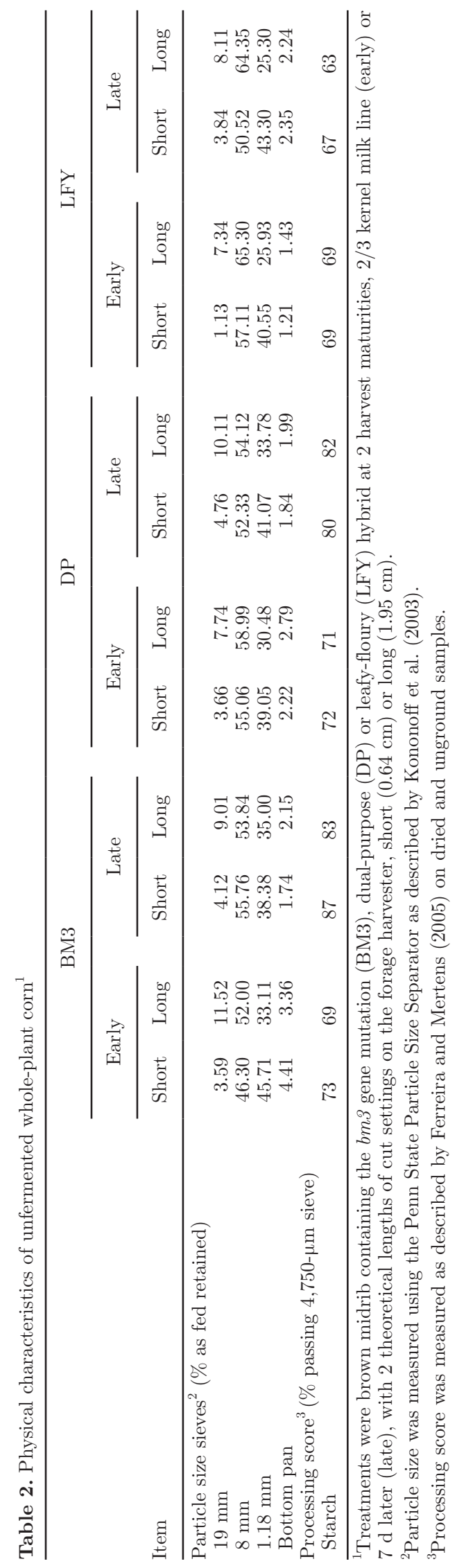


these maturities on total yield of digestible starch. As expected, DM, CP, and lignin contents increased with advanced maturity, but starch and NDF contents did not follow a consistent pattern across hybrids. Lignin content was $1.2 \%$ units lower and ivNDFD $12.6 \%$ units greater for BM3 compared with other hybrids in agreement with previous literature (Ferraretto and Shaver, 2015). Fiber fractions were measured only on fresh samples to characterize the corn forage used in the present study, but not evaluated in ensiled samples because ivNDFD has been reported to be minimally affected by ensiling time or exogenous protease addition (Young et al., 2012; Ferraretto et al., 2015d). Fermentation profile of fresh forage was not different among all hybrids and maturities.

Particle size and kernel processing score for total plant material measured on the 3 hybrids at both maturities and TLOC settings are presented in Table 2. Particle size was minimally affected by hybrid or maturity but increased with longer TLOC settings as expected. Short-TLOC samples, on average, had less material retained on the coarse (3.5 vs. $9.0 \%)$ and medium (52.9 vs. $58.1 \%$ ) sieves, but more material retained on the fine sieve (41.3 vs. $30.6 \%$ ) than long-TLOC samples. Material on the pan was similar between TLOC settings and averaged 2.3\%. Kernel processing score was variable among all samples and was not affected by the TLOC setting. The BM3 and DP, but not LFY, samples had greater kernel processing scores for late than early maturity. This may relate to the greater whole-plant DM content for these 2 hybrids compared with the LFY hybrid resulting in greater kernel fragmentation by the kernel processor for the drier BM3 and DP kernels (refer to Table 3), as reported by Shinners et al. (2000). Furthermore, only DP had increased starch content at late maturity.

\section{Kernel Characteristics}

Chemical composition and in vitro gas production of unfermented corn kernels are presented in Table 3. Kernel DM content varied among hybrids with the greatest values observed for BM3 and lowest for LFY, and increased with maturity for all 3 hybrids. Accumulation of DM in the kernels was variable among hybrids at a similar harvest stage in previous trials from our laboratory (Ngonyamo-Majee et al., 2008, 2009). Kernels appeared to have more starch and lower $\mathrm{CP}$ concentrations from the BM3 and DP compared with the LFY hybrid. This may be related to the reduced DM content at harvest for LFY kernels (Philippeau and MichaletDoreau, 1997). Soluble CP concentration was similar

Table 3. Chemical composition and in vitro gas production for unfermented corn kernels ${ }^{1}$

\begin{tabular}{|c|c|c|c|c|c|c|}
\hline \multirow[b]{2}{*}{ Item } & \multicolumn{2}{|c|}{ BM3 } & \multicolumn{2}{|c|}{$\mathrm{DP}$} & \multicolumn{2}{|c|}{ LFY } \\
\hline & Early & Late & Early & Late & Early & Late \\
\hline \multicolumn{7}{|l|}{ Nutrient } \\
\hline DM (\% of as fed) & 66.8 & 70.9 & 62.9 & 67.6 & 57.5 & 60.5 \\
\hline $\mathrm{CP}(\%$ of $\mathrm{DM})$ & 8.6 & 9.2 & 8.7 & 8.6 & 10.1 & 9.6 \\
\hline Soluble CP (\% of CP) & 28.2 & 25.1 & 28.3 & 25.8 & 27.9 & 27.6 \\
\hline NDF (\% of DM) & 6.7 & 7.0 & 7.2 & 7.7 & 7.1 & 7.8 \\
\hline Starch (\% of DM) & 72.8 & 72.2 & 72.0 & 71.4 & 69.6 & 69.2 \\
\hline Ether extract ( $\%$ of DM) & 3.1 & 3.4 & 3.6 & 3.6 & 3.9 & 4.1 \\
\hline Ash $(\%$ of DM) & 1.3 & 1.4 & 1.4 & 1.4 & 1.4 & 1.5 \\
\hline \multicolumn{7}{|l|}{ Endosperm } \\
\hline Vitreousness (\% of endosperm) & 63.5 & 70.0 & 56.8 & 73.3 & 52.9 & 65.1 \\
\hline \multicolumn{7}{|l|}{ Zein protein profile } \\
\hline Total zein (\% of DM) & 3.4 & 3.7 & 2.6 & 3.4 & 4.5 & 3.8 \\
\hline Total zein (\% of CP) & 39.9 & 40.5 & 29.9 & 40.0 & 44.4 & 39.3 \\
\hline Total zein (\% of starch) & 4.7 & 5.1 & 3.6 & 4.8 & 6.4 & 5.5 \\
\hline$\alpha$ zein $(\%$ of DM $)$ & 2.3 & 2.5 & 2.0 & 2.0 & 2.4 & 2.2 \\
\hline$\alpha$ zein $(\%$ of $\mathrm{CP})$ & 26.8 & 27.3 & 23.3 & 23.4 & 23.7 & 23.3 \\
\hline$\alpha$ zein $(\%$ of starch) & 3.2 & 3.5 & 2.8 & 2.8 & 3.4 & 3.2 \\
\hline$\beta, \gamma, \delta$ zein $(\%$ of DM) & 1.2 & 0.8 & 0.8 & 1.2 & 1.3 & 1.4 \\
\hline$\beta, \gamma, \delta$ zein $(\%$ of $\mathrm{CP})$ & 13.7 & 8.2 & 9.6 & 14.5 & 13.3 & 14.1 \\
\hline$\beta, \gamma, \delta$ zein (\% of starch) & 1.6 & 1.0 & 1.2 & 1.7 & 1.9 & 2.0 \\
\hline \multicolumn{7}{|l|}{ In vitro gas production ${ }^{2}$} \\
\hline PAR (mL/0.1 g of DM per h) & 2.3 & 1.8 & 2.5 & 2.1 & 2.2 & 2.2 \\
\hline Time of PAR $(\mathrm{h})$ & 7.8 & 8.5 & 7.8 & 7.3 & 8.5 & 7.8 \\
\hline Maximum cumulative gas $(\mathrm{mL} / 0.1 \mathrm{~g}$ of $\mathrm{DM})$ & 32.0 & 31.4 & 34.9 & 33.4 & 31.8 & 31.6 \\
\hline $0-12 \mathrm{~h}$ gas production $(\%)$ & 60.6 & 58.8 & 66.0 & 64.9 & 64.9 & 63.6 \\
\hline $12-24 \mathrm{~h}$ gas production (\%) & 39.4 & 41.2 & 34.0 & 35.1 & 35.1 & 36.4 \\
\hline
\end{tabular}

${ }^{1}$ Treatments were brown midrib containing the bm3 gene mutation (BM3), dual-purpose (DP), or leafy-floury (LFY) hybrid.

${ }^{2} \mathrm{PAR}=$ peak absolute rate. 

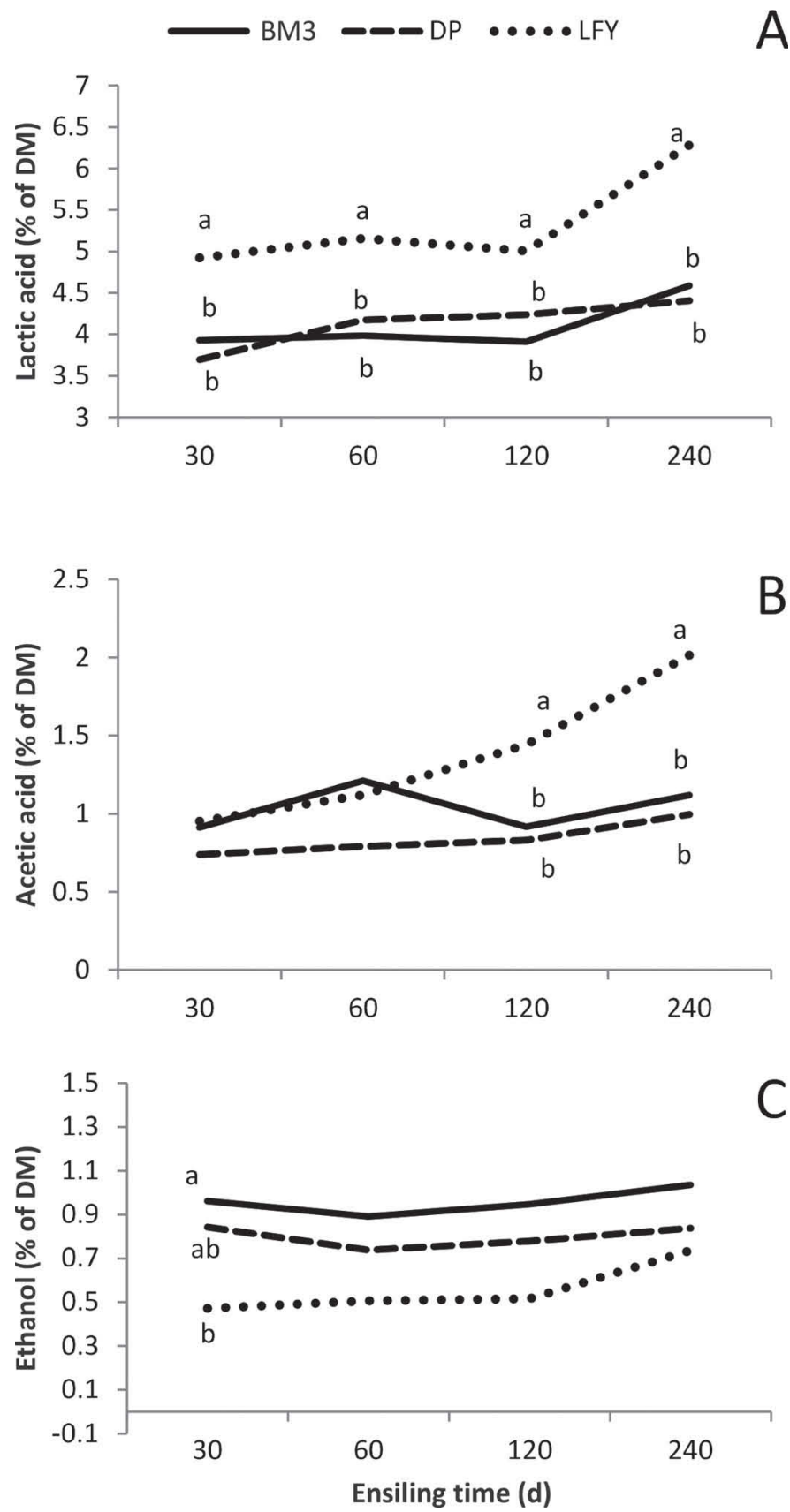

Figure 1. Interaction between ensiling time and hybrids for lactic acid $(\mathrm{A} ; P=0.001 ; \mathrm{SEM}=0.26)$, acetic acid $(\mathrm{B} ; P=0.001 ; \mathrm{SEM}=$ $0.22)$, and ethanol $(\mathrm{C} ; P=0.02 ; \mathrm{SEM}=0.21)$ concentrations. $\mathrm{DP}=$ dual-purpose; LFY = leafy-floury; BM3 = brown midrib containing the $b m 3$ gene mutation. Means within the same day with different letters $(\mathrm{a}, \mathrm{b})$ differ $(P<0.05)$.

among hybrids and decreased with maturity for all 3 hybrids. In contrast, content of NDF was similar among hybrids and increased with maturity. Ash concentration was similar across hybrids and maturities and averaged $1.4 \%$. Ether extract content was slightly higher for LFY than BM3 kernels. Variation in kernel DM and
A nutrient concentrations between hybrids suggest that recommendations for harvesting based on maturity may vary depending on the hybrid grown. Kernel vitreousness was numerically lower in LFY kernels than BM3 and DP kernels at both maturities, but the value for DP was lower than BM3 at the early but not later maturity. The vitreousness range in the present study was similar to the range of 14 commercially available hybrids in the United States reported by Correa et al. (2002). A negative relationship between kernel vitreousness and ivSD has been reported in the literature (Philippeau and Michalet-Doreau, 1997; Correa et al., 2002 ), in agreement with the lower in vitro gas production from 0 to $12 \mathrm{~h}$ for BM3 compared with the other hybrids observed in the present study. Kernel zein contents and profiles, however, were similar among the 3 hybrids. A positive relationship between zein content and vitreousness has been previously reported by Philippeau et al. (2000) and Lopes et al. (2009) in corn grain. Data comparing WPCS hybrids, however, is limited, and further research is necessary to better understand the relationship among kernel vitreousness, zein protein, and starch digestibility in WPCS hybrids. In addition, maximum cumulative gas, peak absolute rate, and time of peak absolute rate was similar across hybrids and maturities and averaged $32.5 \mathrm{~mL} / 0.1 \mathrm{~g}$ of $\mathrm{DM}, 2.2 \mathrm{~mL} / 0.1 \mathrm{~g}$ of $\mathrm{DM} / \mathrm{h}$, and $8 \mathrm{~h}$, respectively.

\section{Fermentation Profile}

Hybrid $\times$ ensiling time interactions were observed $(P<0.01)$ for $\mathrm{pH}$, lactate, acetate, ethanol, and total acid concentrations. Measurements of $\mathrm{pH}$ (data not presented in figure) were lower for BM3 and LFY (3.70 on average) than DP (3.78) on d 30, lower for LFY than BM3 on d 60 and 120 (3.67 vs. 3.73 on average, respectively), and lower for LFY than DP on $240 \mathrm{~d}$ (3.68 vs. 3.75 , respectively). In contrast, no interaction was observed by Der Bedrosian et al. (2012), whereas Ferraretto et al. (2015d) reported a more rapid $\mathrm{pH}$ decline for BM3 than LFY. Lactate (1.2-\% units on average; Figure 1A) and total acid (1.7\%-units on average; data not presented in figure) concentrations were greater for LFY than the other hybrids on d 30,60, 120, and 240. A similar pattern was observed for acetate with greater concentrations for LFY on d 120 and 240 (0.8-\% units on average; Figure 1B). Ethanol content was greater on d 30 for BM3 compared with LFY (0.96 vs. 0.47\%, respectively; Figure 1C). Hybrid $\times$ ensiling time interactions may be related to the lower DM content $(P=$ 0.01; Table 4) observed for the LFY than other hybrids. In addition, a hybrid $\times$ exogenous protease addition interaction was observed for ethanol $(P=0.03$; Figure 2 ) with lower ethanol concentrations for protease than 
Table 4. Effect of hybrid on fermentation profile and ruminal in vitro starch digestibility in whole-plant corn silage $^{1}$

\begin{tabular}{lccccc}
\hline Item & BM3 & DP & LFY & SEM & $P$-value \\
\hline DM (\% as fed) & $45.7^{\mathrm{a}}$ & $46.1^{\mathrm{a}}$ & $34.5^{\mathrm{b}}$ & 0.4 & 0.01 \\
CP (\% of DM) & $8.1^{\mathrm{b}}$ & $7.7^{\mathrm{b}}$ & $8.8^{\mathrm{a}}$ & 0.1 & 0.02 \\
Soluble CP (\% of DM) & $3.65^{\mathrm{b}}$ & $3.72^{\mathrm{b}}$ & $4.57^{\mathrm{a}}$ & 0.07 & 0.02 \\
Soluble CP (\% of CP) & 45.2 & 48.1 & 51.7 & 0.8 & 0.06 \\
Ammonia-N (\% of DM) & 0.45 & 0.44 & 0.54 & 0.02 & 0.09 \\
Ammonia-N (\% of CP) & 5.61 & 5.67 & 6.11 & 0.22 & 0.39 \\
Starch (\% of DM) & $40.2^{\mathrm{a}}$ & $43.4^{\mathrm{a}}$ & $33.9^{\mathrm{b}}$ & 0.6 & 0.02 \\
ivSD (\% of starch) $_{\text {pH }}^{57.2^{\mathrm{c}}}$ & $62.6^{\mathrm{b}}$ & $67.7^{\mathrm{a}}$ & 0.7 & 0.02 \\
Lactic acid (\% of DM) & 3.72 & 3.73 & 3.67 & 0.02 & 0.17 \\
Acetic acid (\% of DM) & 4.10 & 4.13 & 5.34 & 0.24 & 0.11 \\
Ethanol (\% of DM) & 1.04 & 0.84 & 1.38 & 0.20 & 0.35 \\
Total acids (\% of DM) & 0.96 & 0.80 & 0.56 & 0.21 & 0.53 \\
\hline
\end{tabular}

${ }^{a-c}$ Means in the same row with different superscripts differ $(P \leq 0.05)$.

${ }^{1}$ Treatments were brown midrib containing the bm3 gene mutation (BM3), dual-purpose (DP), or leafy-floury (LFY) hybrid ensiled from 30 to $240 \mathrm{~d}$.

${ }^{2}$ Ruminal in vitro starch digestibility at $7 \mathrm{~h}$.

control in DP and LFY WPCS. In contrast, a high dosage of exogenous protease addition increased ethanol concentration in the studies of Young et al. (2012) and Windle et al. (2014).

Maturity $\times$ ensiling time interactions were observed $(P<0.01)$ for $\mathrm{pH}$, lactate, ethanol, and total acid concentrations. Although $\mathrm{pH}$ was similar between early and late harvest on d 30 (3.72 on average), it was greater for late than early maturity from d 60 to 240 (3.64 vs. 3.76 on average, respectively; Figure $3 \mathrm{~A}$ ). A later decline in $\mathrm{pH}$ for late WPCS was previously reported (Der Bedrosian et al., 2012) and may be related to decreased bacterial growth due to low water availability (Muck, 1988). Lactate (Figure 3B) and total acid (data not presented in figure) concentrations were greater for early than late harvest on d 30 and 240, and support this premise. Similar results were reported by Der Bed-

\section{$\square$ Control $\square$ Protease}

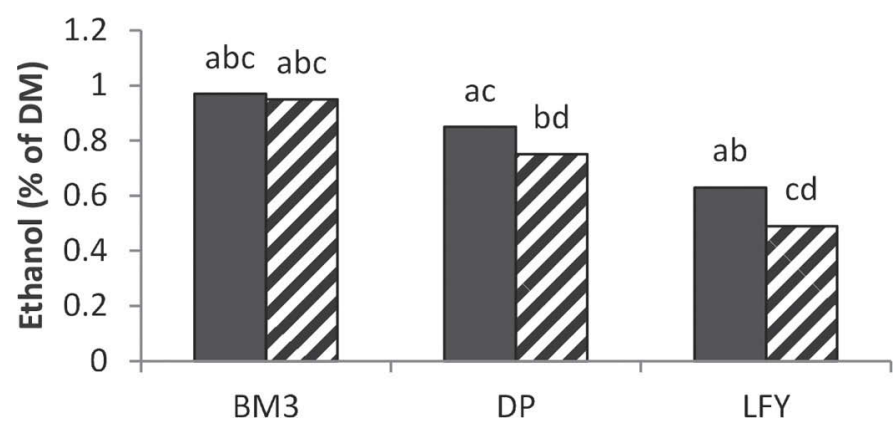

Figure 2. Interaction between hybrids and exogenous protease addition for ethanol $(P=0.03$; SEM $=0.21)$ concentration. BM3 $=$ brown midrib containing the $b m 3$ mutation; $\mathrm{DP}=$ dual-purpose; LFY $=$ leafy-floury. Means within the same day with different letters (a-d) differ $(P<0.05)$. rosian et al. (2012) and Windle et al. (2014). Corn silage harvested at late maturity had 2-fold greater ethanol concentrations on d 30,60, and 120 (Figure 3C) than early. Greater ethanol concentrations in late maturity WPCS was reported by Der Bedrosian et al. (2012). However, the ethanol increase ceased at d 90 for early harvest but increased steadily up to d 360 for late in their trial. Lack of a maturity effect on concentrations of acetate (Table 5), a well-known antifungal agent (Muck, 2010), may explain the difference between the Der Bedrosian et al. (2012) and the present study. No maturity $\times$ exogenous protease addition interactions were observed $(P>0.10)$.

Effects of chop length and exogenous protease addition on fermentation profile are presented in Tables 6 and 7 , respectively. A chop length $\times$ exogenous protease addition interaction was observed for lactate $(P=0.03$; Figure 4$)$ and total acid $(P=0.02$; data not presented in figure) concentrations. Lactate (4.69 vs. $4.37 \%$, respectively) and total acid (5.86 vs. $5.39 \%$, respectively) concentrations were greater for long than short WPCS when both were treated with protease. An interaction for chop length $\times$ ensiling time was observed $(P=0.02$; Figure 5) for ethanol content with $0.2 \%$-units greater values for long WPCS on d 120.

\section{Nitrogen Fractions and Starch Digestibility}

Concentration of $\mathrm{CP}$ was greater for LFY compared with BM3 and DP $(P=0.02$; Table 4$)$. No effects of maturity and chop length on CP content were observed (Tables 5 and 6, respectively). Although exogenous protease addition $(P=0.03$; Table 7$)$ and ensiling time $(P=0.001$; Table 8$)$ effects were observed, the magnitude of the differences were small (range $=0.1$ - and 
0.3-\% units for exogenous protease and ensiling time, respectively). A hybrid $\times$ ensiling time interaction was observed $(P=0.05$; data not presented in figure) with greater starch concentrations for DP than BM3 from d 30 to 120 but not on d 240. Starch concentration was lowest for LFY throughout all ensiling times. Starch concentration was unaffected by maturity (Table 5) and chop length (Table 6). However, a 1.3-\% unit decrease in starch concentration was observed $(P=0.001$; Table 7) with exogenous protease addition.

A hybrid $\times$ exogenous protease addition interaction was observed ( $P=0.07$; data not presented in a figure) for soluble CP; addition of protease increased the concentration of soluble CP by 1.4-\% units in LFY but not BM3 or DP WPCS. However, no hybrid $\times$ exogenous protease addition interactions were observed (Appendix Tables A1 and A2) for ammonia-N content or ivSD. The use of exogenous protease as a silage additive was previously reported to increase soluble $\mathrm{N}$ and ivSD of WPCS (Young et al., 2012). To our knowledge, ours is the first study to evaluate the use of an exogenous protease in WPCS of varied endosperm types and our results indicate that at this dosage protease did not attenuate the negative effects of hybrid on ivSD $(P=$ 0.02; Table 4). Perhaps a higher dosage of exogenous protease may be necessary, and further in vitro and in vivo research is warranted. Maturity $\times$ exogenous protease addition interactions were not observed (Appendix Table A1) for soluble $\mathrm{CP}$ and ammonia-N concentrations. However, exogenous protease addition increased $(P=0.03$; Figure 6$)$ ivSD by $3.2-\%$ units in late but not in early harvest WPCS. Although exogenous protease addition appears to be an option when WPCS is harvested late, ivSD remained lower for late WPCS treated with protease at ensiling $(62.5 \%)$ than untreated early WPCS (65.0\%) suggesting that at this dosage protease may partially attenuate but cannot fully overcome the negative effects of maturity on ivSD. Perhaps a higher dosage of exogenous protease may be necessary and further research is warranted. These results emphasize the importance of proper maturity at harvest to optimize starch digestibility and utilization by dairy cows (Ferraretto and Shaver, 2012b). In contrast, similar ivSD was observed between early and late WPCS with the use of protease as a silage additive after $150 \mathrm{~d}$ of storage in the study by Windle et al. (2014). However, they observed benefits of protease addition at ensiling on ivSD at 2 maturities. Chop length $\times$ exogenous protease addition interactions were not observed (Appendix Tables A1 and A2) for soluble CP, ammonia-N, or ivSD. Samples were ground through a 4-mm sieve before ivSD measurements, which may have attenuated the difference in ivSD between WPCS of different chop lengths. Greater ivSD was observed with addition of this same exogenous protease to rehydrated and high-moisture corn ensiled for $30 \mathrm{~d}$ (Ferraretto et al., 2015c).

A hybrid $\times$ ensiling time interaction was observed $(P=0.001$; Figure $7 \mathrm{~A})$ for ammonia-N (\% of $\mathrm{CP})$; with greater ammonia-N concentration for LFY than
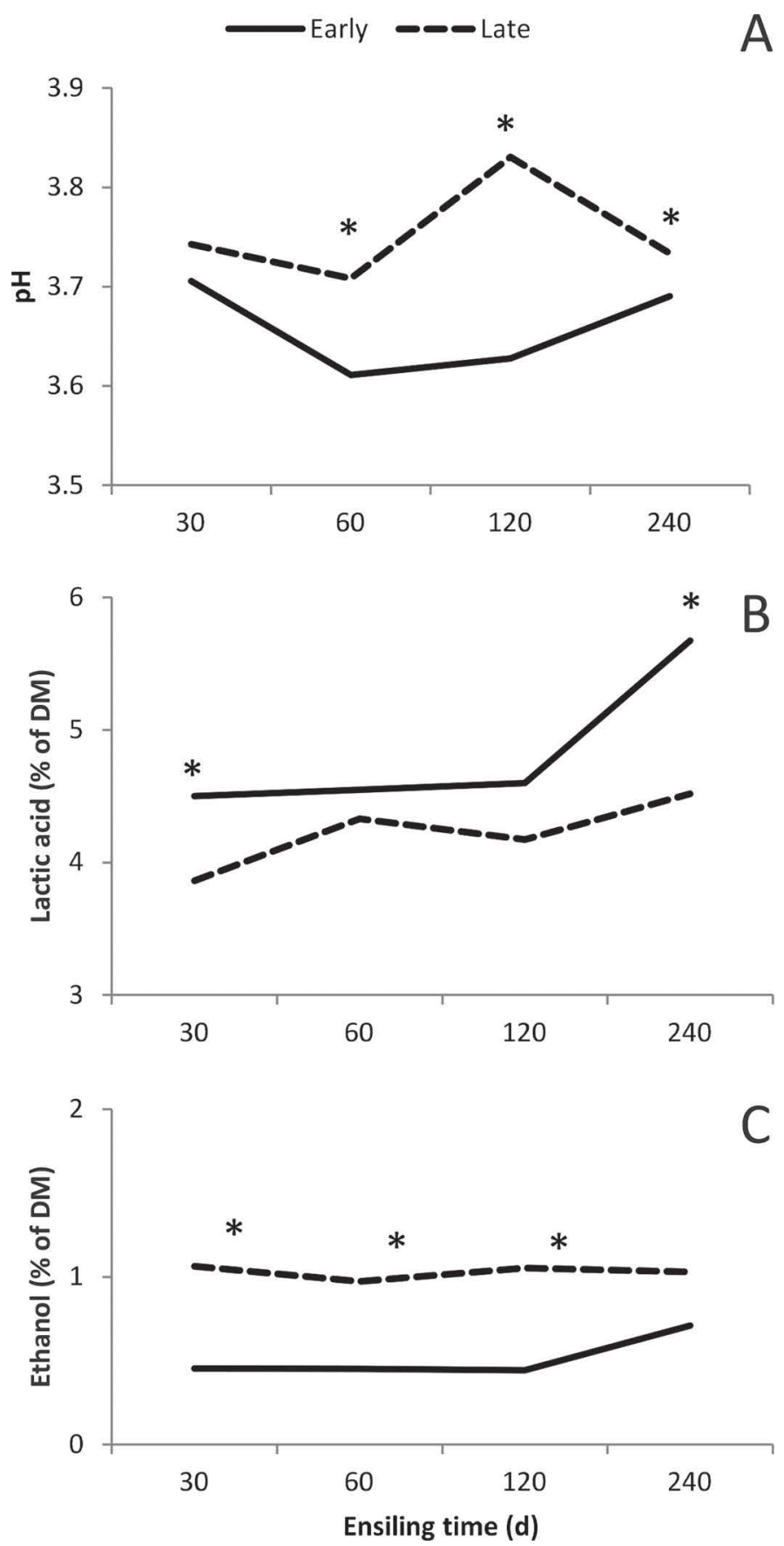

Figure 3. Interaction between ensiling time and maturity for $\mathrm{pH}$ $(\mathrm{A} ; P=0.01 ; \mathrm{SEM}=0.01)$, lactic acid $(\mathrm{B} ; P=0.001 ; \mathrm{SEM}=0.21$ ), and ethanol $(\mathrm{C} ; P=0.001 ; \mathrm{SEM}=0.18)$ concentrations. Means within the same day with an asterisk differ $(P<0.05)$. 
Table 5. Effect of maturity on fermentation profile and ruminal in vitro starch digestibility in whole-plant corn silage ${ }^{1}$

\begin{tabular}{lcccc}
\hline Item & Early & Late & SEM & $P$-value \\
\hline DM (\% as fed) & 40.1 & 44.0 & 0.3 & 0.02 \\
CP (\% of DM) & 8.1 & 8.3 & 0.1 & 0.12 \\
Soluble CP (\% of DM) & 3.90 & 4.07 & 0.06 & 0.17 \\
Soluble CP (\% of CP) & 47.8 & 48.9 & 0.7 & 0.37 \\
Ammonia-N (\% of DM) & 0.46 & 0.49 & 0.01 & 0.26 \\
Ammonia-N (\% of CP) & 5.66 & 5.94 & 0.18 & 0.38 \\
Starch (\% of DM) & 38.5 & 39.8 & 0.5 & 0.22 \\
ivSD ${ }^{2}$ (\% of starch) & 64.7 & 60.9 & 0.6 & 0.05 \\
pH & 3.66 & 3.75 & 0.01 & 0.03 \\
Lactic acid (\% of DM) & 4.83 & 4.22 & 0.20 & 0.16 \\
Acetic acid (\% of DM) & 1.08 & 1.09 & 0.16 & 0.99 \\
Ethanol (\% of DM) & 0.52 & 1.03 & 0.18 & 0.18 \\
Total acids (\% of DM) & 5.91 & 5.31 & 0.33 & 0.33 \\
\hline
\end{tabular}

${ }^{1}$ Treatments were whole-plant corn silage harvested at 2 maturities, $2 / 3$ kernel milk line (early) or $7 \mathrm{~d}$ later (late), and ensiled from 30 to $240 \mathrm{~d}$.

${ }^{2}$ Ruminal in vitro starch digestibility at $7 \mathrm{~h}$.

Table 6. Effect of chop length on fermentation profile and ruminal in vitro starch digestibility in whole-plant corn silage ${ }^{1}$

\begin{tabular}{lcccc}
\hline Item & Short & Long & SEM & $P$-value \\
\hline DM (\% as fed) & 42.1 & 42.0 & 0.3 & 0.77 \\
CP (\% of DM) & 8.2 & 8.2 & 0.1 & 0.75 \\
Soluble CP (\% of DM) & 3.95 & 4.00 & 0.06 & 0.57 \\
Soluble CP (\% of CP) & 47.9 & 48.7 & 0.7 & 0.49 \\
Ammonia-N (\% of DM) & 0.47 & 0.48 & 0.01 & 0.80 \\
Ammonia-N (\% of CP) & 5.75 & 5.85 & 0.18 & 0.73 \\
Starch (\% of DM) & 39.7 & 38.6 & 0.5 & 0.20 \\
ivSD (\% of starch) & 61.2 & 64.4 & 0.6 & 0.07 \\
pH & 3.70 & 3.71 & 0.01 & 0.42 \\
Lactic acid (\% of DM) & 4.44 & 4.61 & 0.15 & 0.12 \\
Acetic acid (\% of DM) & 1.05 & 1.12 & 0.12 & 0.40 \\
Ethanol (\% of DM) & 0.72 & 0.83 & 0.18 & 0.33 \\
Total acids (\% of DM) & 5.49 & 5.73 & 0.24 & 0.17 \\
\hline
\end{tabular}

${ }^{1}$ Treatments were whole-plant corn silage harvested with 2 theoretical lengths of cut settings on the forage harvester, short $(0.64 \mathrm{~cm})$ or long $(1.95 \mathrm{~cm})$, and ensiled from 30 to $240 \mathrm{~d}$.

${ }^{2}$ Ruminal in vitro starch digestibility at $7 \mathrm{~h}$.

Table 7. Effect of exogenous protease addition on fermentation profile and ruminal in vitro starch digestibility in whole-plant corn silage ${ }^{1}$

\begin{tabular}{lcccc}
\hline Item & Control & Protease & SEM & $P$-value \\
\hline DM (\% as fed) & 41.9 & 42.2 & 0.3 & 0.34 \\
CP (\% of DM) & 8.2 & 8.1 & 0.1 & 0.03 \\
Soluble CP (\% of DM) & 3.98 & 3.98 & 0.05 & 0.95 \\
Soluble CP (\% of CP) & 48.1 & 48.6 & 0.5 & 0.21 \\
Ammonia-N (\% of DM) & 0.48 & 0.48 & 0.01 & 0.93 \\
Ammonia-N (\% of CP) & 5.77 & 5.83 & 0.13 & 0.34 \\
Starch (\% of DM) & 39.8 & 38.5 & 0.4 & 0.001 \\
ivSD ${ }^{2}$ (\% of starch) & 62.2 & 63.4 & 0.6 & 0.13 \\
pH & 3.72 & 3.69 & 0.01 & 0.02 \\
Lactic acid (\% of DM) & 4.52 & 4.53 & 0.15 & 0.88 \\
Acetic acid (\% of DM) & 1.08 & 1.10 & 0.12 & 0.79 \\
Ethanol (\% of DM) & 0.82 & 0.73 & 0.13 & 0.001 \\
Total acids (\% of DM) & 5.60 & 5.63 & 0.24 & 0.78
\end{tabular}

${ }^{1}$ Treatments were whole-plant corn silage without (Control) or with exogenous protease addition at ensiling (Protease) ensiled from 30 to $240 \mathrm{~d}$.

${ }^{2}$ Ruminal in vitro starch digestibility at $7 \mathrm{~h}$. 
Control $\square$ Protease

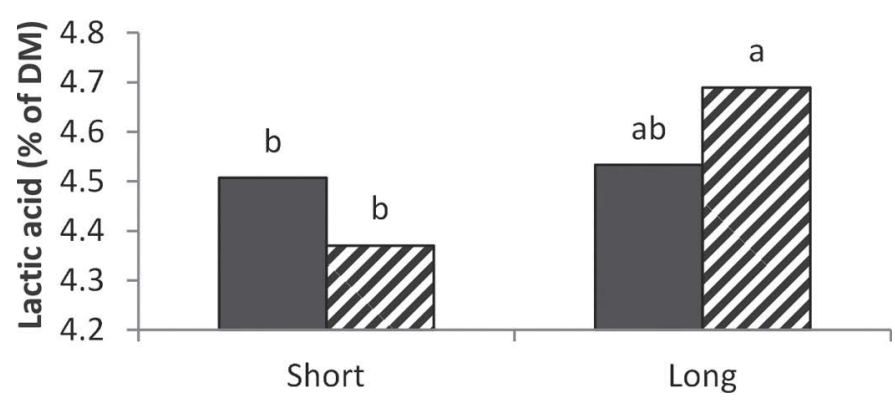

Figure 4. Interaction between whole-plant corn silage chop length and exogenous protease addition for lactic acid $(P=0.03$; SEM $=$ $0.15)$ concentration. Means within the same day with different letters (a,b) differ $(P<0.05)$.

other hybrids on d 240. Likewise, a hybrid $\times$ ensiling time interaction was observed $(P=0.001$; Figure $7 \mathrm{~B})$ for soluble $\mathrm{CP}$ (\% of $\mathrm{CP}$ ). Soluble $\mathrm{CP}$ concentration was greater for LFY than other hybrids on d 30, and greatest for LFY and lowest for BM3 on d 120 and 240. However, a hybrid $\times$ ensiling time interaction was not observed (Appendix Table A2) for ivSD. These results are contrary to our hypothesis that increased ensiling time would attenuate the effects of vitreousness on ivSD $(P=0.02$; Table 4$)$. The literature is equivocal with regard to the effects of ensiling time on WPCS of different hybrids. When WPCS was harvested at $41 \%$ DM, BM3 had similar ivSD compared with conventional WPCS as fresh forage but lower ivSD from 45 to $360 \mathrm{~d}$ of ensiling (Der Bedrosian et al., 2012). In contrast, the authors observed that when WPCS was harvested at 32\% DM, the BM3 took $270 \mathrm{~d}$ to reach the same ivSD as conventional WPCS. Increased ammonia$\mathrm{N}$ and soluble CP concentrations for LFY compared

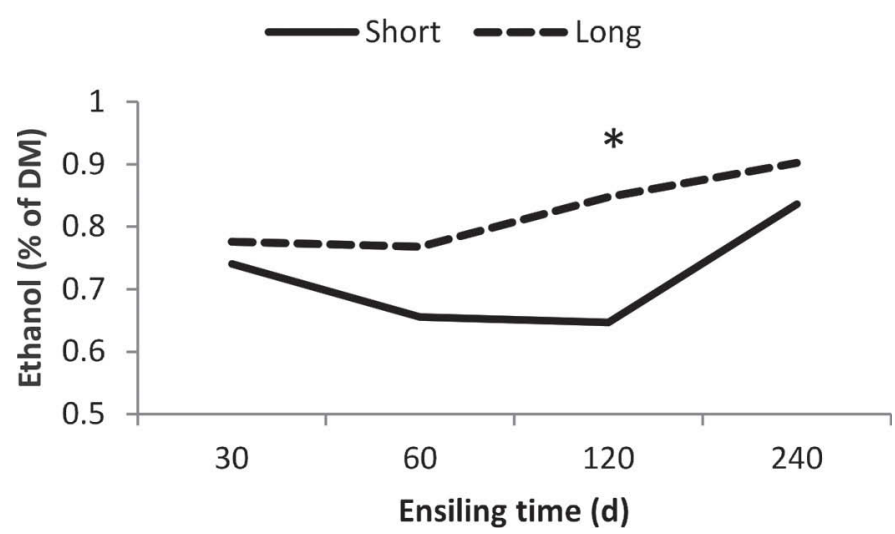

Figure 5. Interaction between whole-plant corn fresh forage and silage chop length and ensiling time for ethanol concentration $(P=$ 0.03 ; SEM $=0.13)$. Means within the same day with an asterisk differ $(P<0.05)$ $\square$ Control $\square$ Protease

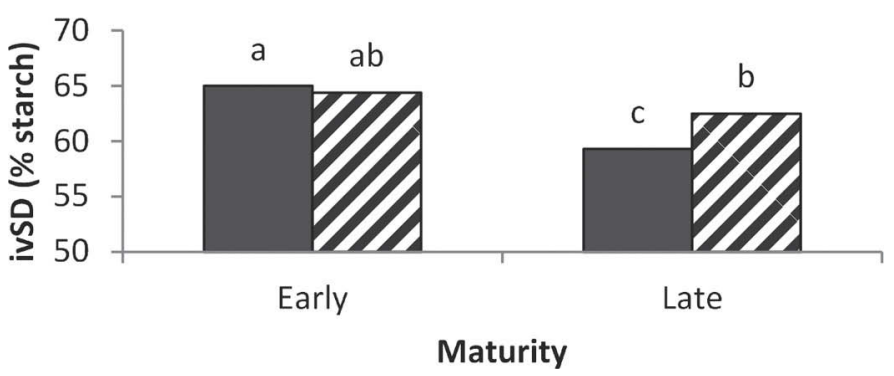

Figure 6. Interaction between maturity and exogenous protease addition for ruminal in vitro starch digestibility (ivSD; $P=0.03$; SEM $=0.85)$. Means within the same day with different letters $(\mathrm{a}-\mathrm{c})$ differ $(P<0.05)$.

with BM3 after 120 d of ensiling were observed in a previous experiment from our laboratory (Ferraretto et al., 2015d). However, ivSD increased similarly for both hybrids over the ensiling period in that trial. In vivo starch digestibility comparisons of WPCS hybrids differing in vitreousness, however, are scarce in the literature. Two hybrids, with low and high vitreousness, at varied maturities and processing settings were evaluated by Johnson et al. (2002a,b). The authors observed a negative relationship between kernel vitreousness and total-tract starch digestibility in lactating dairy cows, although this relationship was greater in unprocessed compared with processed WPCS. Interestingly, however, less floury endosperm was observed in the low vitreousness hybrid. Szasz et al. (2007) reported similar ruminal and total-tract starch digestibility in feedlot steers when comparing high-moisture corn harvested from a floury versus a vitreous corn hybrid. In situ effective ruminal disappearance of starch also did not differ and measurements of kernel vitreousness were not reported.

A maturity $\times$ ensiling time interaction was observed $(P=0.03$; data not presented in figure); with greater ammonia-N concentration for LT than ER on d 60 (5.17 vs. $4.63 \%$, respectively). However, no interaction was observed for soluble CP (Appendix Table A1). Similar results were observed by Windle et al. (2014). In addition, ensiling time did not (lack of a maturity $\times$ ensiling time interaction; Appendix Table A2) attenuate the negative effects of maturity on ivSD $(P=$ 0.05; Table 5). Combined, these results do not support the observations of Owens (2014) that fermentation in the silo eliminates either the difference between floury and vitreous endosperms of unfermented kernels or the negative effects of maturity on starch digestibility. No chop length $\times$ ensiling time interactions for soluble $\mathrm{CP}$, ammonia-N, and ivSD were observed (Appendix Tables A1 and A2). However, samples were ground through a 
Table 8. Effect of storage length on fermentation profile and ruminal in vitro starch digestibility in whole-plant corn silage

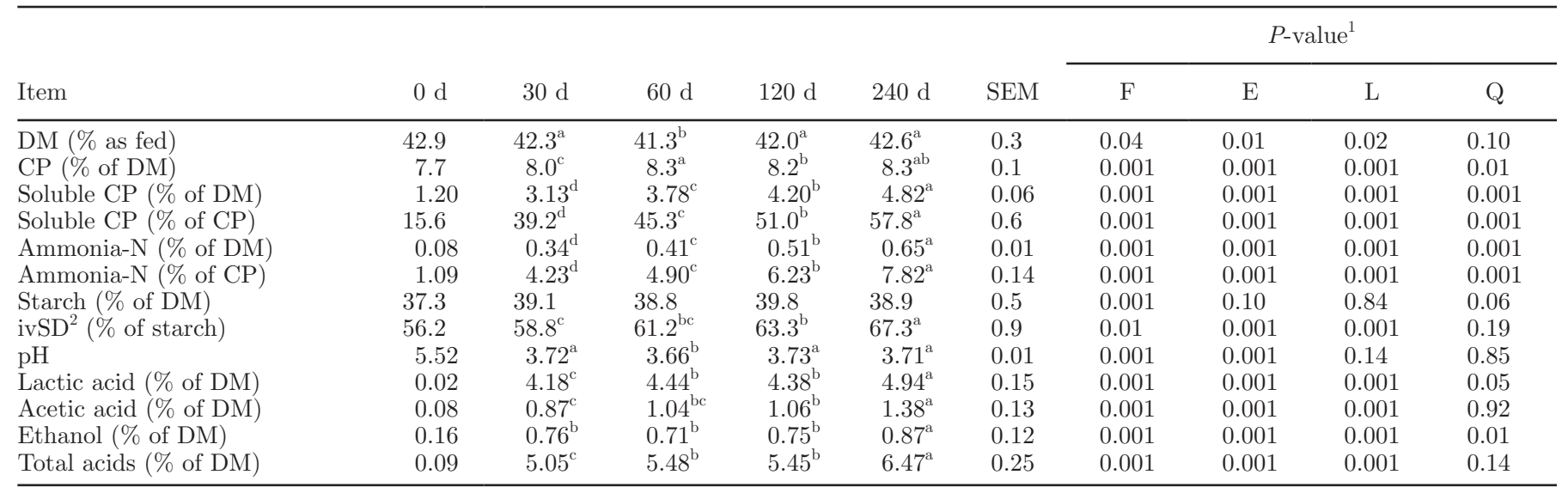

${ }^{\mathrm{a} e}$ Means in the same row with different superscripts differ $(P \leq 0.05)$. Treatment comparisons between 30, 60, 120, and $240 \mathrm{~d}$.

${ }^{1} \mathrm{~F}=$ fermentation effect ( 0 vs. $30 \mathrm{~d}$ ), $\mathrm{E}=$ ensiling time effect (from d 30 to 240 ), $\mathrm{L}=$ linear effect and $\mathrm{Q}=$ quadratic effect comparisons between $\mathrm{d} 30$ and 240 .

${ }^{2}$ Ruminal in vitro starch digestibility at $7 \mathrm{~h}$.
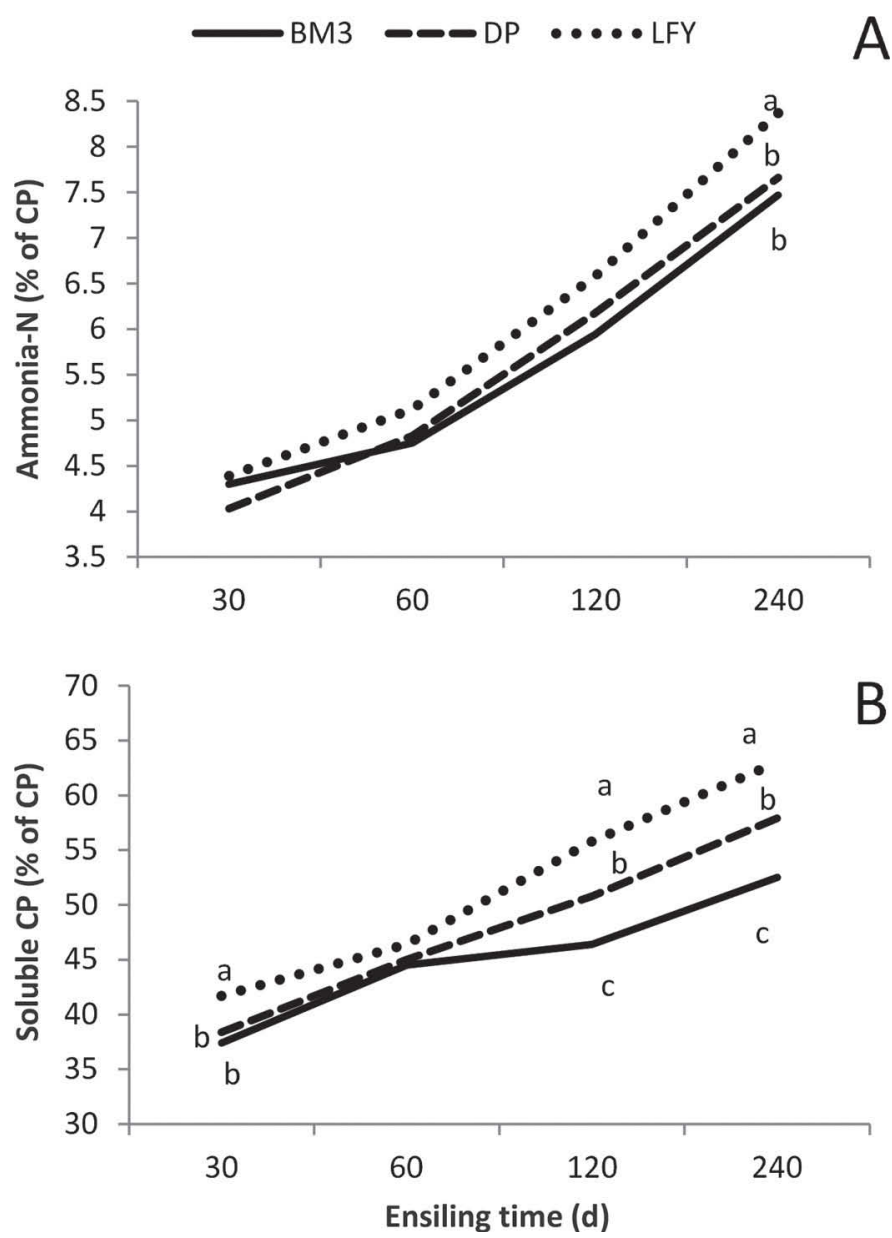

Figure 7. Interaction between ensiling time and hybrids for ammonia-N $(\mathrm{A} ; P=0.01 ; \mathrm{SEM}=0.23)$ and soluble $\mathrm{CP}(\mathrm{B} ; P=0.001$; $\mathrm{SEM}=0.99)$ concentrations. $\mathrm{BM} 3=$ brown midrib containing the $b m_{3}$ mutation; DP = dual-purpose; LFY = leafy-floury. Means within the same day with different letters $(\mathrm{a}-\mathrm{c})$ differ $(P<0.05)$.
A 4-mm sieve before ivSD measurements, which may have attenuated the difference in ivSD between WPCS of different chop lengths.

\section{CONCLUSIONS}

Extended time in storage increased ammonia-N, soluble CP, and ivSD in WPCS of various hybrids, maturities, and chop lengths. Prolonged storage of WPCS, however, requires proper silo management during filling, packing, and covering to avoid detrimental fermentation patterns. Contrary to our hypothesis, however, extended ensiling time did not alter the negative effects of vitreousness and maturity at harvest on ivSD. These results do not support the dogma that fermentation in the silo eliminates the differences in ivSD between

B WPCS of varied maturities and hybrids. Exogenous protease addition did not attenuate the negative effects of vitreousness on ivSD. In addition, despite the positive effects of exogenous protease addition on ivSD observed for late maturity WPCS, it did not overcome the negative effects of maturity on ivSD. Perhaps a higher dosage of exogenous protease may be necessary and further research is warranted. No interactions between chop length and ensiling time or exogenous protease addition on ivSD were observed. Overall, these results emphasize the importance of hybrid selection, proper maturity at harvest, kernel processing, and ensiling time to achieve maximum ivSD of WPCS.

\section{ACKNOWLEDGMENTS}

Appreciation is extended to USDA Hatch Act Formula (fund \#WIS01719) and to DSM Nutritional 
Products/Novozymes (Basel, Switzerland/Bagsvaerd, Denmark) for partial project funding, and the staff at the University of Wisconsin-Madison Agricultural Research Station for corn production and corn silage harvest.

\section{REFERENCES}

AOAC International. 2012. Official Methods of Analysis. 19th ed. AOAC Int., Arlington, VA.

Bach Knudsen, K. E. 1997. Carbohydrate and lignin contents of plant materials used in animal feeding. Anim. Feed Sci. Technol. 67:319338.

Correa, C. E. S., R. D. Shaver, M. N. Pereira, J. G. Lauer, and K. Kohn. 2002. Relationship between corn vitreousness and ruminal in situ starch degradability. J. Dairy Sci. 85:3008-3012.

Der Bedrosian, M. C., L. Kung Jr., and K. E. Nestor Jr.. 2012. The effects of hybrid, maturity and length of storage on the composition and nutritive value of corn silage. J. Dairy Sci. 95:5115-5126.

Ferraretto, L. F., G. S. Dias Junior, L. C. de Resende, and R. D. Shaver. 2015a. Effect of ensiling on kernel processing score in wholeplant corn silage harvested with varied processors and settings. J. Dairy Sci. 98(Suppl. 2):W202. (Abstr.)

Ferraretto, L. F., A. C. Fonseca, C. J. Sniffen, A. Formigoni, and R. D Shaver. 2015b. Effect of corn silage hybrids differing in starch and NDF digestibility on lactation performance and total tract nutrient digestibility by dairy cows. J. Dairy Sci. 98:395-405.

Ferraretto, L. F., S. M. Fredin, and R. D. Shaver. 2015c. Influence of ensiling, exogenous protease addition and bacterial inoculation on fermentation profile, nitrogen fractions and ruminal in vitro starch digestibility in rehydrated and high-moisture corn. J. Dairy Sci. 98:7318-7327. http://dx.doi.org/10.3168/jds.2015-9891.

Ferraretto, L. F., and R. D. Shaver. 2012a. Effect of corn shredlage on lactation performance and total tract starch digestibility by dairy cows. Prof. Anim. Sci. 28:639-647.

Ferraretto, L. F., and R. D. Shaver. 2012b. Meta-analysis: Impact of corn silage harvest practices on intake, digestion and milk production by dairy cows. Prof. Anim. Sci. 28:141-149.

Ferraretto, L. F., and R. D. Shaver. 2015. Effects of whole-plant corn silage hybrid type on intake, digestion, ruminal fermentation, and lactation performance by dairy cows through a meta-analysis. J. Dairy Sci. 98:2662-2675.

Ferraretto, L. F., R. D. Shaver, S. Massie, R. Singo, D. M. Taysom, and J. P. Brouillette. 2015d. Effect of ensiling time and hybrid type on fermentation profile, nitrogen fractions and ruminal in vitro starch and NDF digestibility in whole-plant corn silage. Prof. Anim. Sci. 31:146-152.

Ferreira, G., and D. R. Mertens. 2005. Chemical and physical characteristics of corn silages and their effects on in vitro disappearance. J. Dairy Sci. 88:4414-4425.

Ganoe, K. H., and G. W. Roth. 1992. Kernel milkline as a harvest indicator for corn silage in Pennsylvania. J. Prod. Agric. 5:519-523.

Goering, H. K., and P. J. Van Soest. 1970. Forage fiber analyses (apparatus, reagents, procedures, and some applications). ARS/USDA Handbook No. 379, Superintendent of Documents, US Government Printing Office, Washington, DC.

Hoffman, P. C., N. M. Esser, R. D. Shaver, W. K. Coblentz, M. P. Scott, A. L. Bodnar, R. J. Schmidt, and R. C. Charley. 2011. Influence of ensiling time and inoculation on alteration of the starchprotein matrix in high-moisture corn. J. Dairy Sci. 94:2465-2474.

Hoffman, P. C., D. R. Mertens, J. Larson, W. K. Coblentz, and R. D. Shaver. 2012. A Query for effective mean particle size of dry and high moisture corns. J. Dairy Sci. 95:3467-3477.

Johnson, L. M., J. H. Harrison, D. Davidson, J. L. Robutti, M. Swift, W. C. Mahanna, and K. Shinners. 2002a. Corn silage management I: Effects of hybrid, maturity, and mechanical processing on chemical and physical characteristics. J. Dairy Sci. 85:833-853.
Johnson, L. M., J. H. Harrison, D. Davidson, M. Swift, W. C. Mahanna, and K. Shinners. 2002b. Corn silage management II: Effects of hybrid, maturity, and mechanical processing on digestion and energy content. J. Dairy Sci. 85:2913-2927.

Kononoff, P. J., A. J. Heinrichs, and D. R. Buckmaster. 2003. Modification of the Penn State forage and total mixed ration particle separator and the effects of moisture content on its measurements. J. Dairy Sci. 86:1858-1863.

Kotarski, S. F., R. D. Waniska, and K. K. Thurn. 1992. Starch hydrolysis by the ruminal microflora. J. Nutr. 122:178-190.

Krishnamoorthy, U., T. V. Muscato, C. J. Sniffen, and P. J. Van Soest. 1982. Borate phosphate procedure as detailed in nitrogen fractions in selected feedstuffs. J. Dairy Sci. 65:217-225.

Lopes, J. C., R. D. Shaver, P. C. Hoffman, M. S. Akins, S. J. Bertics, H. Gencoglu, and J. G. Coors. 2009. Type of corn endosperm influences nutrient digestibility in lactating dairy cows. J. Dairy Sci. 92:4541-4548.

Masoero, F., A. Gallo, C. Zanfi, G. Giuberti, and M. Spanghero. 2011. Effect of nitrogen fertilization on chemical composition and rumen fermentation of different parts of plants of three corn hybrids. Anim. Feed Sci. Technol. 164:207-216.

McAllister, T. A., H. D. Bae, G. A. Jones, and K. J. Cheng. 1994 Microbial attachment and feed digestion in the rumen. J. Anim. Sci. 72:3004-3018.

McAllister, T. A., R. C. Phillippe, L. M. Rode, and K. J. Cheng. 1993. Effect of the protein matrix on the digestion of cereal grains by ruminal microorganisms. J. Anim. Sci. 71:205-212.

Muck, R. E. 1988. Factors affecting silage quality and their implications for management. J. Dairy Sci. 71:2992-3002.

Muck, R. E. 2010. Silage microbiology and its control through additives. Rev. Bras. Zootec. 39:183-191. (Supl. Especial).

Muck, R. E., and J. T. Dickerson. 1988. Storage temperature effects on proteolysis in alfalfa silage. Trans. ASABE 31:1005-1009.

National Oceanic and Atmospheric Administration. 2015. Monthly station temperature, precipitation, and heating and cooling degree days 1995-2014. National Oceanic and Atmospheric Administration Online Weather Data. Accessed Feb. 19, 2015. http://www. weather.gov/climate/xmacis.php? $\mathrm{wfo}=\mathrm{mkx}$.

Nellis, S. E., P. C. Hoffman, and R. D. Shaver. 2013. Technical note: A modified method to quantify prolamin proteins in dry and highmoisture corn. J. Dairy Sci. 96:4647-4652.

Ngonyamo-Majee, D., R. D. Shaver, J. G. Coors, D. Sapienza, and J. G. Lauer. 2008. Relationship between kernel vitreousness and DM degradability for diverse corn germplasm. II. Ruminal and postruminal degradabilities. Anim. Feed Sci. Technol. 142:259-274.

Ngonyamo-Majee, D., R. D. Shaver, J. G. Coors, D. Sapienza, and J. G. Lauer. 2009. Influence of single-gene mutations, harvest maturity and sample processing on ruminal in situ and post-ruminal in vitro dry matter and starch degradability of corn grain by ruminants. Anim. Feed Sci. Technol. 151:240-259.

Owens, F. 2014. New technologies in forage varieties and production. Pages 103-121 in Proc. Tri-State Dairy Nutr. Conf., Ft. Wayne, IN. Ohio State Univ., Columbus.

Philippeau, C., J. Landry, and B. Michalet-Doreau. 2000. Influence of the protein distribution of maize endosperm on ruminal starch degradability. J. Sci. Food Agric. 80:404-408.

Philippeau, C., and B. Michalet-Doreau. 1997. Influence of genotype and stage of maturity of maize on rate of ruminal starch degradation. Anim. Feed Sci. Technol. 68:25-35.

Richards, C. J., J. F. Peterson, R. A. Britton, R. A. Stock, and C. R. Krehbiel. 1995. In vitro starch disappearance procedure modifications. Anim. Feed Sci. Technol. 55:35-45.

SAS Institute Inc. 2004. SAS/STAT 9.1 User's Guide. Version 9.1 ed. SAS Institute Inc., Cary, NC.

Seglar, W. J., and R. D. Shaver. 2014. Management and assessment of ensiled forages and high-moisture grain. Vet. Clin. North Am. Food Anim. Pract. 30:507-538.

Shinners, K. J., A. G. Jirovec, R. D. Shaver, and M. A. Bal. 2000. Processing whole-plant corn silage with crop processing rolls on a pull-type forage harvester. Appl. Eng. Agric. 16:323-331. 
Szasz, J. I., C. W. Hunt, P. A. Szasz, R. A. Weber, F. N. Owens, W. Kezar, and O. A. Turgeon. 2007. Influence of endosperm vitreousness and kernel moisture at harvest on site and extent of digestion of high-moisture corn by feedlot steers. J. Anim. Sci. 85:2214-2221.

Windle, M. C., N. Walker, and L. Kung Jr.. 2014. Effects of an exogenous protease on the fermentation and nutritive value of corn silage harvested at different dry matter contents and ensiled for various lengths of time. J. Dairy Sci. 97:3053-3060.

Young, K. M., J. M. Lim, M. C. Der Bedrosian, and L. Kung Jr.. 2012. Effect of exogenous protease enzymes on the fermentation and nutritive value of corn silage. J. Dairy Sci. 95:6687-6694.

\section{APPENDIX}

Table A1. Statistical analysis ( $P$-values) of the interaction effects of ensiling time (ET), hybrids (H), maturity (M), chop length (CL), and exogenous protease addition $(\mathrm{P})$ on nutrient composition in whole-plant corn silage

\begin{tabular}{|c|c|c|c|c|c|c|c|}
\hline Item & $\begin{array}{c}\text { DM } \\
(\% \text { as fed })\end{array}$ & $\begin{array}{c}\mathrm{CP} \\
(\% \text { of } \mathrm{DM})\end{array}$ & $\begin{array}{l}\text { Soluble CP } \\
(\% \text { of DM) }\end{array}$ & $\begin{array}{l}\text { Soluble CP } \\
\text { (\% of CP) }\end{array}$ & $\begin{array}{c}\text { Ammonia-N } \\
(\% \text { of } \mathrm{DM})\end{array}$ & $\begin{array}{c}\text { Ammonia-N } \\
(\% \text { of } \mathrm{CP})\end{array}$ & $\begin{array}{c}\text { Starch } \\
(\% \text { of DM) }\end{array}$ \\
\hline $\mathrm{H} \times \mathrm{CL}$ & 0.42 & 0.78 & 0.85 & 0.94 & 0.87 & 0.87 & 0.47 \\
\hline $\mathrm{M} \times \mathrm{CL}$ & 0.84 & 0.84 & 0.92 & 0.99 & 0.74 & 0.74 & 0.35 \\
\hline $\mathrm{M} \times \mathrm{P}$ & 0.97 & 0.11 & 0.07 & 0.12 & 0.87 & 0.53 & 0.12 \\
\hline $\mathrm{M} \times \mathrm{ET}$ & 0.26 & 0.19 & 0.27 & 0.27 & 0.05 & 0.03 & 0.57 \\
\hline $\mathrm{P} \times \mathrm{ET}$ & 0.81 & 0.70 & 0.76 & 0.71 & 0.50 & 0.38 & 0.63 \\
\hline $\mathrm{H} \times \mathrm{CL} \times \mathrm{P}$ & 0.03 & 0.81 & 0.51 & 0.34 & 0.82 & 0.82 & 0.39 \\
\hline $\mathrm{H} \times \mathrm{CL} \times \mathrm{ET}$ & 0.44 & 0.18 & 0.11 & 0.26 & 0.13 & 0.11 & 0.67 \\
\hline $\mathrm{H} \times \mathrm{P} \times \mathrm{ET}$ & 0.32 & 0.65 & 0.78 & 0.29 & 0.66 & 0.86 & 0.01 \\
\hline $\mathrm{M} \times \mathrm{CL} \times \mathrm{P}$ & 0.55 & 0.19 & 0.97 & 0.52 & 0.94 & 0.79 & 0.51 \\
\hline $\mathrm{M} \times \mathrm{CL} \times \mathrm{ET}$ & 0.69 & 0.11 & 0.59 & 0.46 & 0.36 & 0.04 & 0.58 \\
\hline $\mathrm{M} \times \mathrm{P} \times \mathrm{ET}$ & 0.52 & 0.35 & 0.65 & 0.67 & 0.93 & 0.73 & 0.13 \\
\hline
\end{tabular}

Table A2. Statistical analysis ( $P$-values) of the interaction effects of ensiling time (ET), hybrids $(\mathrm{H})$, maturity $(\mathrm{M})$, chop length $(\mathrm{CL})$, and exogenous protease addition $(\mathrm{P})$ on fermentation profile and starch digestibility in whole-plant corn silage

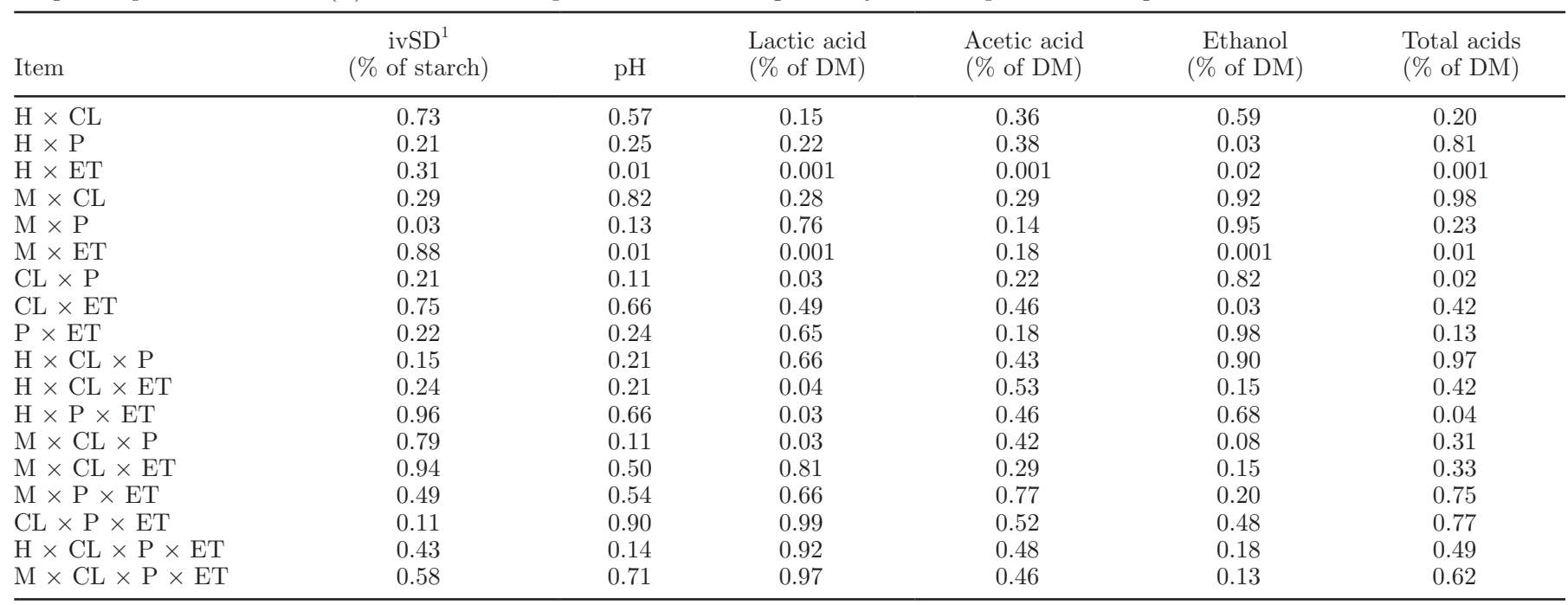

${ }^{1}$ Ruminal in vitro starch digestibility at $7 \mathrm{~h}$. 